\title{
ВЗАЄМОЗВ ЯЗЗК МІЖ СТІЙКИМ РОЗВИТКОМ ТА ЗБАЛАНСОВАНОЮ РЕСУРСНОЮ ПОЛІТИКОЮ ПІДПРИЄМСТВА
}

\author{
Пілявський Володимир Іванович \\ кандидат економічних наук \\ Міжнародний університет бізнесу і права (м.Херсон, Україна) \\ ORCID: 0000-0003-3311-0559 \\ v.piliavskyi@ukr.net
}

В статті проаналізовано характер впливу економічних, соціальних, технологічних, фрінансових компонентів на економічне зростання в умовах складної економічної ситуації на основі збалансованої ресурсної політики підприємства. Складна економічна ситуація змушує підприємства аграрного сектору економіки шукати й використовувати нові фрактори росту, що визначають розробку сучасних механізмів управління, які спрямовані на інтенсифікацію відтворювального процесу й підвищення есрективності виробництва.

А отже, найважливішим питанням економічної науки на сьогодні є економічна стійкість функціонування підприємств, яка визначається великою кількістю фракторів, а саме: соціально-економічними умовами господарювання, рівнем техніки й технології виробництва, наявністю науково-технічного та ресурсного потенціалу, кваліфрікованого кадрового складу тощо. Саме соціальний, технологічний, фінансовий компоненти ресурсного потенціалу сприяють отриманню економічної ренти і гарантують стійкі конкурентні переваги, а специфічні і унікальні ресурсні складники забезпечують нейтралізацію загроз з боку зовнішнього економічного середовища і сприяють формуванню системи цінностей для споживачів.

Ключові слова: підприємство, економічна стійкість, стійкий розвиток, ресурсний потенціал підприємства, збалансований ресурсний розвиток, економічне зростання, оптимізація функціонування підприємства.

DOI: https://doi.org/10.32845/bsnau.2019.2.10

Постановка проблеми. Складна економічна ситуація змушує підприємства аграрного сектору економіки шукати й використовувати нові фактори росту, що визначають розробку сучасних механізмів управління, які спрямовані на інтенсифікацію відтворювального процесу й підвищення ефективності виробництва.

А отже, найважливішим питанням економічної науки на сьогодні $€$ економічна стійкість функціонування підприємств, яка визначається великою кількістю факторів, а саме: соціально-економічними умовами господарювання, рівнем техніки й технології виробництва, наявністю науково-технічного та ресурсного потенціалу, кваліфікованого кадрового складу тощо. Саме соціальний, технологічний, фінансовий компоненти ресурсного потенціалу сприяють отриманню економічної ренти і гарантують стійкі конкурентні переваги, а специфічні і унікальні ресурсні складники забезпечують нейтралізацію загроз з боку зовнішнього економічного середовища і сприяють формуванню системи цінностей для споживачів.

Аналіз останніх досліджень і публікацій. Концептуальні підходи до вирішення проблеми забезпечення економічної стійкості сільськогосподарських підприємств викладені в працях Т. Бердникової, Л. Борисоглібської, І. Гончар, Н. Давиденко, І. Демидова, Т. Керанчук, М. Крейніної, В. Крохмаля, Л. Ляха, С. Михайлова, О. Мороз,І. Маркіної, О. Онищенка, С. Плєсняєвої, Г. Саєнко, В. Соченко, В. Ткачука, В. Шевцова та ін. Проте залишається коло невирішених питань.

Метою статті $€$ виявлення характеру впливу економічних, соціальних, технологічних, фінансових компонентів на економічне зростання в умовах складної економічної ситуації на основі збалансованої ресурсної політики підприємства.

Виклад основних результатів дослідження. У літературних джерелах економічна стійкість розглядається в до-

сить різних значеннях. Проведений аналіз існуючих визначень цього поняття показав, що вони є досить обґрунтованими і безперечними, хоча й вимагають деяких уточнень. Економічна стійкість - це ґрунтовна характеристика підприємства за певний період часу, яка відображає здатність підтримувати ключові фінансові, маркетингові, виробничі й кадрові показники на нормативно заданому з високим ступенем імовірності рівні під впливом викликів зовнішнього й внутрішнього середовища.

Стійкий розвиток підприємства можна розглядати в якості свого роду компенсаційного механізму, що дозволяє підприємству не просто адаптуватися до дестабілізуючого впливу внутрішнього і зовнішнього середовища, але і неухильно розвиватися. Чим вище стійкість розвитку підприємства, тим менше ризик можливого відхилення від очікуваного результату і навпаки.

В умовах ринку загальна стійкість підприємства потребує в першу чергу стабільного одержання виручки, достатньої за розміром, щоб можна було розрахуватися з державою, постачальниками, кредиторами, працівниками власного підприємства. Одночасно для його розвитку необхідно, щоб після здійснення всіх розрахунків і виконання всіх зобов'язань у нього залишався прибуток, який дозволяє розвивати виробництво та модернізувати його матеріально-технічну базу, поліпшувати соціальний клімат в колективі тощо. Інакше кажучи, загальна стійкість підприємства допускає насамперед такий рух грошових потоків, який забезпечує постійне перевищення надходження коштів доходів над їх витратами.

Аналіз складу структурних компонентів ресурсного потенціалу сільськогосподарських підприємств показав (рис.1.), що його основу становлять чотири основні компоненти: соціальний, технологічний, фінансовий і природний. 


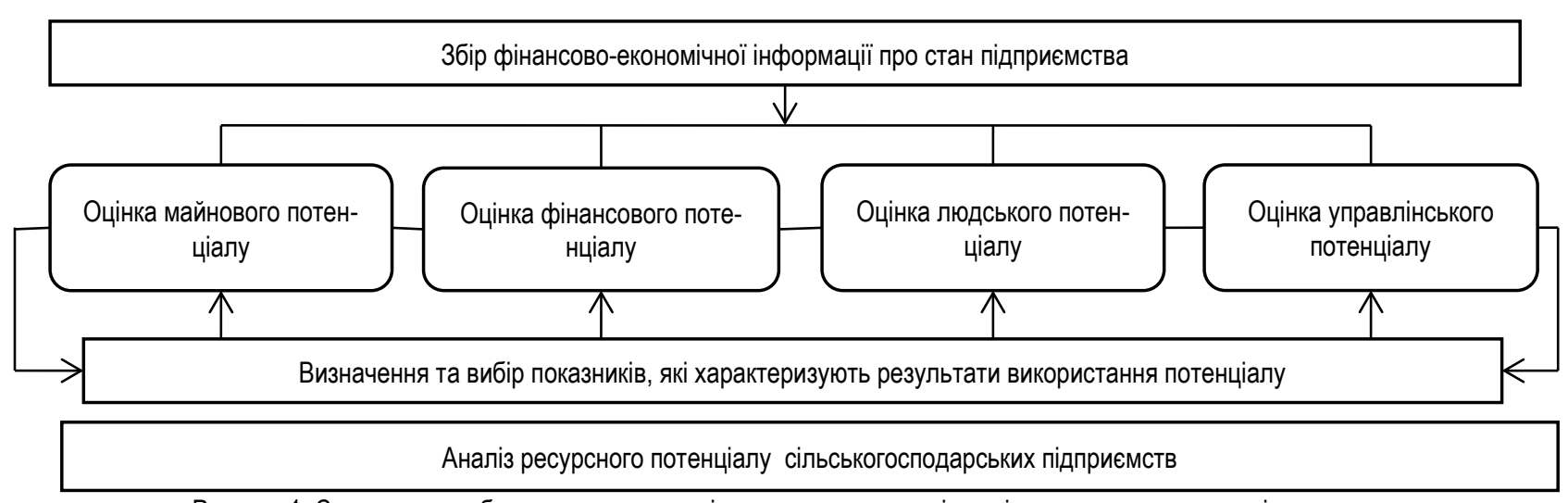

Рисунок 1. Схематичне зображення компонентів ресурсного потенціалу сільськогосподарських підприємств *Джерело: сформовано автором

Соціальний компонент це трудові ресурси, а саме здатність апарату управління, колективу і працівників сільськогосподарських підприємств ефрективно використовувати наявні ресурсів. Виробничий компонент потенціалу сільськогосподарських підприємств зумовлюється залученням у виробництво основних та оборотних засобів,земельного потенціалу. Природний компонент визначається сприятливими для ведення сільськогосподарського виробництва кліматичними умовами. Фінансовий компонент визначається наявними інвестиціями в грошовій формі, які дозволяють забезпечувати безперебійний процес сільськогосподарського виробництва та власними ресурсами капіталізація яких, призводить до збільшення ринкової вартості підприємства[5,с.175]. Значимість ресурсів виявляється в процесі виробництва і характеризується їх впливом на результати діяльності сільськогосподарських підприємств.

Величина значимості елементів не є сталим розміром і змінюється в міру залучення до процесу виробництва нових елементів, зміни якості і співвідношення, а також, при переході до сучасної стадії розвитку, із зміною економічної парадигми, що зумовлює необхідність корінних змін в організації і особливо в її системі управління. Як слідство, виникає проблема раціонального ведення господарства. Основною метою якого є досягнення відповідної результативності при справедливих витратах ресурсів.

В умовах обмеженості ресурсів проблема економічного вибору непереборна, але в різних економічних системах вона вирішується по різному. У традиційному суспільстві - вибір залежить від традицій і звичаїв; в командній економіці - від волі, правлячої еліти; в ринковому господарстві - від ринкової кон'юнктури. Використовуючи в процесі функціонування цілу сукупність факторів виробництва, які мають різну економічну природу та сутність, сільськогосподарські підприємства стикаються із проблемою визначення оптимальних ресурсних пропорцій. Тим більше, що у сільському господарстві в останні часи спостерігається погіршення ресурсної бази, що призводить до значного падіння виробництва конкурентоспроможної продукції. Виходячи з цього, сільськогосподарським підприємствам необхідно оптимально формувати власний ресурсний потенціал. Категорія ресурсного потенціалу

необхідна для оцінки можливостей майбутнього розвитку підприємства, оскільки потрібно враховувати напрями розширення, відтворення та поповнення джерел ресурсів [1,с.322]. В агропромисловому виробництві головною задачею обліку ресурсів є визначення збалансованості виробничих можливостей підприємства, їх теперішньої та майбутньої ринкової затребуваності [2,c.122]. Такий підхід враховує внутрішні виробничі можливості підприємства, дозволяє своєчасно реагувати на коливання у використанні ресурсів. Приведений нижче алгоритм визначення ресурсного потенціалу дозволить сільськогосподарському підприємству оцінити свої теперішні можливості, для того, щоб успішно розвиватися у майбутньому ( рис.2.) Дійсно, маючи можливість комбінувати ресурси в різних поєднаннях при виробництві різноманітних видів продукції, сільськогосподарські підприємства при одній тій самій ресурсозабезпеченості можуть обирати альтернативні варіанти для свого розвитку. При чому кожен з таких варіантів буде характеризуватися індивідуальними параметрами.

В сучасних умовах на рівень розвитку виробничих сил суттєво впливає науково-технічний прогрес. Він призводить до: глибоких якісних перетворень у засобах виробництва, більш повного виробітку природних багатств, корінних змін у структурі та організації виробництва, створює нові засоби управління його розвитком. Отже, щоб передбачити шляхи та перспективи подальшого розвитку сільськогосподарського підприємства, необхідним $є$ вивчення закономірностей розвитку виробничих сил за сучасних умова не тільки у теоретичному аспекті, але й у практичному застосуванні[6, с.193]. В умовах сучасної науково-технічної революції співвідношення між елементами виробничих сил $€$ достатньо динамічними. «Оптимальне співвідношення факторів відтворення $€$ найважливішою задачею планування і управління економікою. Диспропорції між особистими та речовими факторами або не відповідність у складі речових факторів призводить до зниження ефективності суспільного виробництва» [3,с.35]. Для досягнення максимальної ефективності суспільного виробництва необхідно знайти оптимальне співвідношення речових та особистих факторів. При цьому необхідно враховувати протиріччя і проблеми, які виникають в процесі їх з'єднання. 


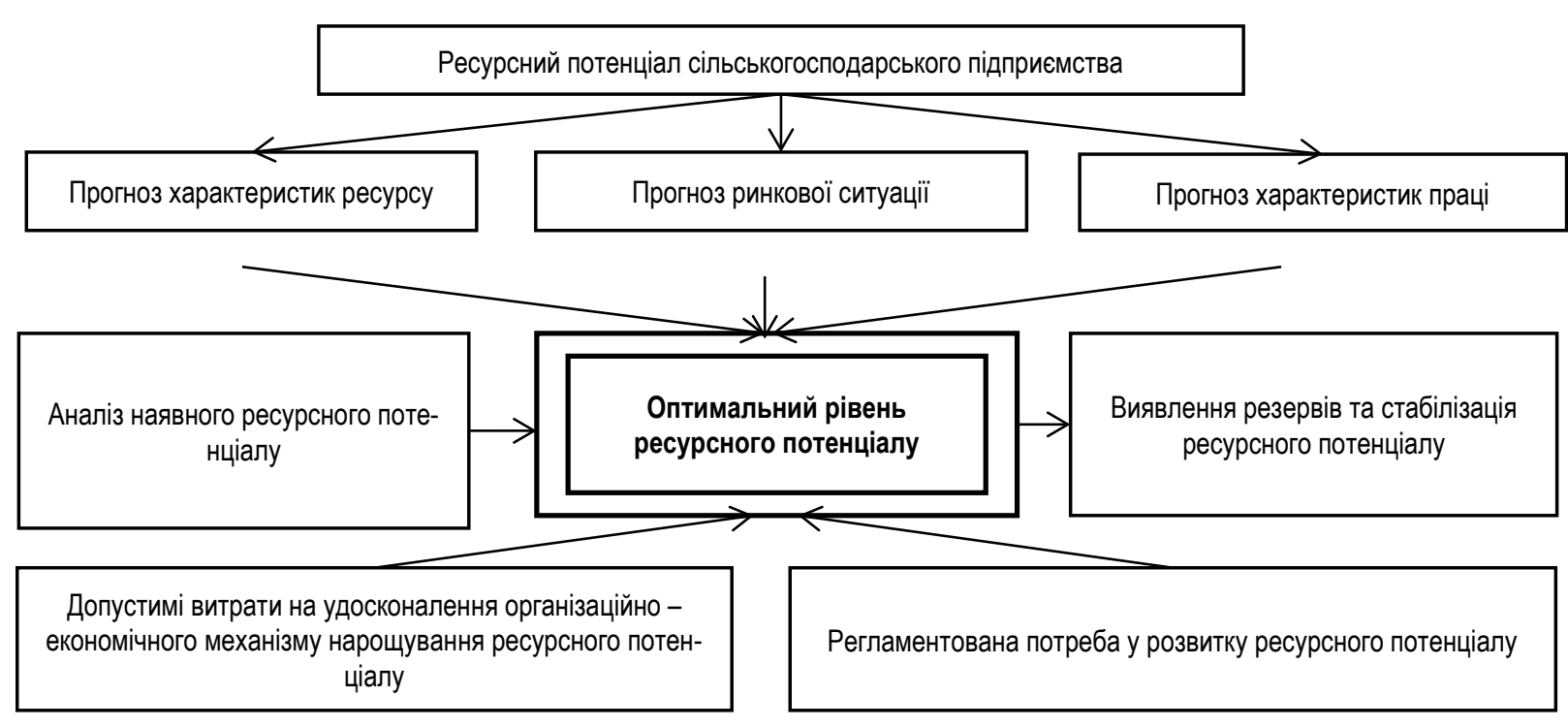

Рисунок 2. Алгоритм визначення оптимального рівня ресурсного потенціалу сільськогосподарського підприємства

*Джерело: сформовано автором

Кількісні пропорції, які утворюються між елементами виробничих сил розкриваються за допомогою такого поняття, як збалансованість. В словнику $[4$, с.121] поняття «збалансованості» трактується як:

- установка рівноваги;

- приведення у відповідне співвідношення між собою взаємопов'язаних сторін будь-якої діяльності;

- стан економіки, при якому кількісні пропорції забезпечують гармонійне поєднання товарних та грошових потоків, стабільність цін та задовільне функціонування економічного апарату;

- стан економічної системи, яка характеризує рівновагу між попитом та пропозицією на ресурси;

- такий стан економічної системи, при якому один із її учасників не зацікавлений в зміні відповідного стану тому, що він нічого не зможе виграти, зможе лише втратити все;

- ситуація при якій, економічна система розвивається так, що при різних діях економічних агентів параметри її розвитку залишаться в допустимих межах.

На думку автора, збалансованість - це стан суб'єкта економічної діяльності, який характеризується науково-обґрунтованими пропорціями між попитом та пропозицією на всі ресурси, що входять до складу ресурсного потенціалу і які забезпечують ефективність його використання.

Таким чином, для ефективного функціонування процесу виробництва необхідним $є$ оптимальне співвідношення між всіма ресурсами, які знаходяться в наявності у сільськогосподарського підприємства. При чому на кожному етапі виробничого циклу їх співвідношення може бути різним. I збалансованість основних факторів виробництва, на основі взаємозамінності, $€$ неодмінною умовою для зростання ефективності виробництва. Заміщення одних ресурсів іншими викликано тим, що існують різні можливості їх нарощування, i тому виникає обмеженість ресурсів.

Проблема збалансованості використання ресурсів найбільш гостро проявляється на стиках взаємопов'язаних галузей. Диспропорції, які досить часто виникають, призводять до втрат живої та уречевленої праці. Так в сільському господарстві виділяють дві взаємопов'язані галузі - рослинництво і тваринництво. Значна кількість кормів, які використовуються в тваринництві вирощуються в рослинництві. Разом 3 цим, більша частина органічних добрив, використовується в рослинництві. Тому встановити правильні пропорції між галузями та в середині них $є$ неодмінною умовою розширеного відтворення. Так ефективність виробництва буде досягнута лише тоді, коли буде змога збалансувати між собою земельні та матеріально-технічні ресурси, основні та оборотні фонди, енергетичні та технічні засоби тощо. Лише визначивши співвідношення між земельними, трудовими та виробничими ресурсами буде можливість отримати відповідну кількість продукції.

Висновки. Виходячи з того, що земельні ресурси обмежені, трудові ресурси, які приймають участь у сільськогосподарському виробництві мають стійку тенденцію до зниження, виникає необхідність збалансовувати елементи виробничих сил з метою оптимального їх використання. До речі, співвідношення між ними достатньо еластичне, тому можливим $€$ скорочення земельних угідь при збільшенні засобів виробництва. Але, скорочення земельних угідь нижче певної межі вже не дозволить сільськогосподарському підприємству отримати задану кількість продукції, а частина інших ресурсів підприємства буде не задіяною. Однак існує і така межа, коли для обробітку землі інших ресурсів буде не достатньо. Відповідно до цього, в сільському господарстві теж існують граничні межі заміни ресурсів, за якими не вдається зберегти обсяги виробленої продукції, а подальша взаємозаміна стає економічно не вигідною. Застосування оптимізаційного економіко-математичного програмування дозволить вибрати із великої кількості варіантів найбільш оптимальний.

Реалізація будь-якої задачі по оптимізації функціонування сільськогосподарського підприємства в якості основи розв'язання використовує наявні обсяги ресурсів, які можна направити на досягнення поставлених цілей. Чіткий опис ресурсного потенціалу в подальшому формалізується в єдину систему ресурсних обмежень. Обмежуючі фактори можна поділити на дві групи: виробничо-технологічні;соціально-економічні.

Виробничо-технологічні обмеження являють собою 
зворотну сторону факторів технологічної взаємозамінності ресурсів, оскільки у кожному виробничому циклі різні способи використання ресурсів та різна їх кількість застосовується при виробництві кінцевого продукту.

Соціально-економічні обмеження відображають внутрішні і зовнішні можливості господарського механізму сільськогосподарського підприємства, які пов'язані з формуванням і використанням ресурсів.

Забезпечення умов для переходу промисловості Ук- раїни на модель сталого розвитку дозволить підвищити її конкурентоспроможність, зміцнити позиції на глобальних ринках, що створить базис для підвищення економічної міцності держави, вирішення екологічних та соціальних проблем. Нажаль, на сьогоднішній день роль національної промисловості в процесах глобалізації $€$ поки що мінімальною: практично немає вітчизняних транснаціональних компаній, які б працювали на глобальних ринках, в Україні надто мала частина дочірніх підприємств світових виробників, низький рівень міжнародних коопераційних зв'язків [7, с.82].

\section{Список літератури:}

1. Економічний розвиток України: інституціональне та ресурсне забезпечення. К.: НАН України ; Об'єднаний ін-т економіки, 2005. 540 C.

2.Ковалев В.В. Финансовыйанализ: методы и процедуры. М.: Финансы и статистика, 2002. с.211.

3. Трегобчук В. Концепція сталого розвитку для України: (формування екологобезпечної економіки, ресурсо-екологічних і природоохоронних проблем). Вісник Національної академії наук України. - 2002. № 2. С. 31 - 40.

4. Методичні рекомендації з бухгалтерського обліку біологічних активів, затверджені наказом Міністерства фінансів України від 29.12.2006 р. № 1315 [Елек- тронний ресурс].Режим доступу : www.rada.com.ua.

5. Терещенко С.І. Фінансовепланування як основа забезпеченнясталогорозвиткупідприємства. НауковийвісникУжгородського ун-ту. Серія Економіка,2009. - Спецвипуск 28. Ч. 2. с.173-177.

6. Терещенко С.І. Ресурсний потенціал підприємства: функції та структура. Збірник наукових праць Національного унту водного госп. та природокор. Серія "Економіка". Рівне: НУВГП, 2012.Вип.. 2(58) с. 191-197.

7.Концепція Загальнодержавної цільової програми розвитку промисловості України на період до 2017 року [Електронний ресурс]. Режим доступу : http://industry.kmu.gov.ua

\section{References:}

1. Economic development of Ukraine: institutional and resource suppor. K .: NAS of Ukraine; United Economics Institute, 2005. $-540 p$.

2. Kovalev VV Financial analysis: methods and procedures. M .: Finance and statistics, 2002. p.211

3. Tregobchuk V. The concept of sustainable development for Ukraine: (formation of ecological economy, resource-ecological and environmental problems). Bulletin of the National Academy of Sciences of Ukraine. 2002. № 2. - P. 31 - 40.

4. Methodological recommendations for accounting of biological assets, approved by the order of the Ministry of Finance of Ukraine dated December 29, 2006 No. 1315 [Electronic resource]. Access mode: www.rada.com.ua.

5. Tereshchenko S.I. Financial planning as a basis for ensuring the sustainable development of the enterprise.Scientific Bulletin of Uzhgorod Univ. Economy Series, 2009. Special issue 28. Part 2. p.173-177.

6. Tereshchenko S.I. Enterprise resource potential: functions and structure. Collection of scientific papers of the National University of Water Management. and nature. Economy series. - Exactly: NUPGP, 2012. Issue 2 (58) . p. 191-197.

7. Concept of the National Target Program for the Development of Industry of Ukraine for the Period to 2017 [Electronic resource]. Access Mode: http://industry.kmu.gov.ua

Piliavsky Volodymyr, PhD, International university of business and law (Kherson, Ukraine)

Communication between sustainable development and a balanced enterprise resource policy

The article analyzes the nature of the impact of economic, social, technological, financial components on economic growth in the conditions of difficult economic situation on the basis of balanced resource policy of the enterprise. The difficult economic situation is forcing the agricultural sector to look for and use new growth factors that determine the development of modern management mechanisms that are aimed at intensifying the reproduction process and improving production efficiency.

Therefore, the most important issue of economic science today is the economic stability of the functioning of enterprises, which is determined by a number of factors, namely: socio-economic conditions of the economy, the level of technology and production technology, the availability of scientific and technical and resource potential, qualified staff. It is the social, technological, financial components of the resource potential that help to generate economic rent and guarantee sustainable competitive advantages, while specific and unique resource components ensure the neutralization of threats from the external economic environment and contribute to the formation of a value system for consumers.

The realization of any task of optimizing the functioning of an agricultural enterprise as the basis of the solution uses the available amounts of resources that can be directed to the achievement of the set goals. A clear description of the resource potential is further formalized into a single system of resource constraints. The limiting factors can be divided into two groups: production and technological; socio-economic.

Production and technological constraints represent the downside of the factors of technological interchangeability of resources, because in each production cycle different ways of using resources and their different amount is used in the production of the final product. 
Socio-economic constraints reflect the internal and external capabilities of an agricultural enterprise's economic mechanism that are associated with the formation and use of resources.

Providing conditions for the transition of the Ukrainian industry to the model of sustainable development will increase its competitiveness, strengthen its position in the global markets, which will create a basis for increasing the economic strength of the country, solving environmental and social problems. Unfortunately, to date, the role of national industry in globalization processes is still minimal: there are practically no domestic multinationals operating in global markets, too few Ukrainian subsidiaries in Ukraine, low international cooperative links

Keywords: enterprise, economic stability, sustainable development, resource potential of enterprise, balanced resource development, economic growth, optimization of enterprise functioning

Дата надходження до редакції: 11.02 .2019 р. 